\title{
Synthesis, Characterization and Antibacterial Evaluation With Computational Study of New Schiff Bases Derived from 7-Hydroxy-4-Methyl Coumarin
}

\section{DANA M. HUSSEIN ${ }^{1}$, SAHAR B. AL-JUBOORY² and AMMAR A.RAZZAK MAHMOOD ${ }^{3, *}$}

\author{
${ }^{1}$ Faculty of Medical Sciences-School of Pharmacy-Dept. of Pharmaceutical Chemistry- \\ University of Sulaimani-Sulaimani-Iraq. \\ ${ }^{2}$ College of Al-Rafiden University- Dept. of Pharmacy-Baghdad-Iraq. \\ ${ }^{3}$ College of Pharmacy-Dept. of Pharmaceutical Chemistry-University of Baghdad- \\ Baghdad-Bab-Almudam-Iraq. \\ ${ }^{*}$ Corresponding author E-mail:kubbaammar1963@gmail.com
}

http://dx.doi.org/10.13005/ojc/330224

(Received: February 21, 2017; Accepted: March 26, 2017)

\begin{abstract}
New derivatives of 7-hydroxy-4-methylcoumarin were synthesized via oxidation of methyl group at $\mathrm{C} 4$ of parent coumarin nucleus using $\mathrm{SeO}_{2}$ as an oxidizing agent. Then the condensation with different aromatic amines and amino acids under conventional method. The structures of the title Schiff bases were elucidated by spectral analysis: FT-IR, ${ }^{13} \mathrm{CNMR}$, and MS.All the compounds were tested in vitro for their preliminary antibacterial activity against two Gram-positive and two Gram -negative bacteria, using serial dilution method, and determining their minimum inhibitory concentrations for the title compounds. Most of the derivatives showed moderate to high antibacterial activity.Compound $\mathbf{7}$ showed a good antibacterial activity against Gram- positive Staphylococcus aureus and Micrococcus luteus also very potent antibacterial activity against Gram-negative E.coli. Density functional theory (DFT)calculations for the synthesized coumarins were performed using a molecular structure with optimized geometry. Molecular orbital calculations supported a full description of the orbitals, including spatial characteristics, nodal patterns, and the contributions of individual atoms. Highest occupied molecular orbital/lowest unoccupied molecular orbital energies and structures are demonstrated.
\end{abstract}

Keywords: Antibacterial activity, broth dilution method, density functional theory(DFT), 7-hydroxy-4-methylcoumarin, Schiff base,

\section{INTRODUCTION}

Coumarins are important class of compounds, they demonstrate useful and different activities, often depending on the substituents they include, benzopyran moiety ${ }^{1,2}$. Coumarins are natural compounds produced by various plant sources. Their structures contain fused benzene and pyrone 
rings. Recently, they have fascinated and attractive research work, due to their remarkable biological and pharmacological activities, which include antibacterial, antifungal, anticoagulant, antioxidant, anticancer, and anti-inflammatory properties ${ }^{3,4}$. Coumarins showed strong antibacterial activity against both Gram-positive and Gram-negative bacteria, especially against Gram-negative bacteria, by damaging cell membrane.

The advantages of coumarins as potential antibacterial compounds, due to their broad range of antibacterial activity; also they are secreted by plants as phytoalexins and have defensive mechanism against attacks from pathogens, and they are environmentally friendly and not vulnerable to develop bacteria resistance ${ }^{4-6}$.

Azomethine group $(-\mathrm{C}=\mathrm{N}-)$ containing compounds usually known as Schiff bases have been synthesized by the treatment of primary amines with active carbonyls. Schiff bases form a significant class of compounds in medicinal chemistry, with diverse biological applications that include antioxidant, antibacterial ${ }^{7-10}$. Coumarins containing a Schiff base moiety are predictable to have improved antitumor and other distinctive activities ${ }^{11}$.

Some literatures show that the reaction of 4-methyl benzo coumarin with selenium dioxide reveals the corresponding 4-formyl derivative, which eventually has been reacted with some primary aromatic amines to get Schiff bases with significant antibacterial activities ${ }^{12}$

Due to the importance and established pharmacological activity of these compounds, the aim of the present work is to synthesize new Schiff bases at C4 of the parent coumarin nucleus, as promising antibacterial agents, against both<smiles>[R][X]c1ccccc1/N=C\c1cc(=O)oc2cc3ccccc3cc12</smiles>

Benzocoumarin schiff bases

$\mathrm{R}=3-\mathrm{NO}_{2}, 4-\mathrm{OCH}_{3}, 4-\mathrm{F}, 4-\mathrm{Cl}$
Gram positive and Gram negative bacteria. Also, a computational study was planned to calculate some thermodynamic parameters. Thus, the synthesis of new series of Schiff bases derived from 7- hydroxyl4-methyl coumarin has been achieved.

\section{MATERIALS AND METHODS}

Chemicals used during the synthesis, supplied by Sigma-Aldrich. Solvents were dried and distilled before use. Completion of reactions and the purity of compounds were ascertained by thin-layer chromatography (TLC) , using Silica gel GF ${ }_{254}$ (type 60) pre-coated Aluminium sheets, Merck (Germany). Melting points were determined using Stuart/SMP3 melting point apparatus version 5.0 in open capillary tubes, and were uncorrected. $\mathrm{IR}(\mathrm{KBr})$ spectra $\mathrm{vcm}^{-1}$ were recorded using Thermo Scientific ${ }^{\mathrm{TM}}$ Nicolet $^{\mathrm{TM}}$ iS $^{\text {TM } 10 ~ F T-I R ~ S p e c t r o m e t e r ~ i n ~ P i o n e e r ~ c o m p a n y ~ f o r ~}$ pharmaceutical industry-Sulaimani-Kurdistan-Iraq. ${ }^{13} \mathrm{C}-\mathrm{NMR}$ spectra were recorded on Bruker FT-NMR spectrophotometer 400, in the College of PharmacyHamedan University of Medical Sciences- HamedanIran, using deuterated dimethyl sulfoxide (DMSO- $\mathrm{d}_{6}$ ) and deuterated chloroform $\left(\mathrm{CDCl}_{3}\right)$ as internal standards. Chemical shifts were expressed in $\delta$ ppm. MS was run at College of Pharmacy-Hamedan University of Medical Sciences- Hamedan-Iran, using Agilent Technology (HP), GC/MS model 5973 network mass selective detector. The values were expressed as $\mathrm{m} / \mathrm{z}$. The synthetic method is depicted in Scheme 1.

\section{Synthesis of 7-hydroxy-4-formyl coumarin $(1)^{13}$ 14 \\ 7-hydroxy-4-methyl coumarin (0.005 mol, 1} g) was dissolved in hot xylene $(50 \mathrm{ml})$, the solution was cooled down and selenium dioxide $(0.009 \mathrm{~mol}$, $1 \mathrm{~g})$ was added. The solution was refluxed for the period of $12 \mathrm{~h}$, then filtered while hot to remove the insoluble selenium. The solvent was removed to get the desired product.

Yellow powder, yield 35\%; m.p. 222-224 ${ }^{\circ} \mathrm{C}$ $\mathrm{IR}(\mathrm{KBr})$ v, $\mathrm{cm}^{-1}: 3233(\mathrm{OH})$ str.,3050 $\mathrm{Ar}(\mathrm{CH})$ str., 2850 $(\underline{\mathrm{H}-\mathrm{C}}=\mathrm{O})$ aldehydic hydrogen str., $1723(\mathrm{C}=\mathrm{O})$ str. of lactone, $1698(\mathrm{C}=\mathrm{O})$ str. of aldehyde, 1599,1516 $(\mathrm{ArC}=\mathrm{C})$ str., $1410(\mathrm{OH})$ phenol bend.,1068(C-O) str. of lactone $\left.;{ }^{13} \mathrm{CNMR}(100 \mathrm{MHz}), \mathrm{DMSO}-\mathrm{d}_{6}, \delta \mathrm{ppm}\right)$ : 194.31(C=O aldehyde),161.54(C=O lactone), 160.78, 
155.26, 127.08,112.49 and 102.57(C aromatic and alkene); mass spectroscopy Calcd. for $\mathrm{C}_{10} \mathrm{H}_{6} \mathrm{O}_{4}$ $(\mathrm{m} / \mathrm{z}, \%): 190[\mathrm{M}]^{+}(27.6 \%), 162[\mathrm{M}-\mathrm{CO}](10 \%), 161[\mathrm{M}-$ $\mathrm{COH}](14.9 \%), 148[\mathrm{M}-$ ketene](100\%) ,104(17\%).

General method for the synthesis of aromatic amine Schiff bases (2-6) ${ }^{15-17}$

Appropriate aromatic amine (0.005) mol of [4-Nitro aniline $0.69 \mathrm{~g}$, 4-amino acetophenone 0.67 g, 4-amino antipyrine 1.01g,4-amino ethyl benzoate $0.82 \mathrm{~g}$, and 2-amino-5-mercapto-1,3,4-thiadiazole $0.66 \mathrm{~g}]$ each was added with continuous stirring to a solution of compound 1, (0.005 mol, $0.95 \mathrm{~g})$ and two drops of glacial acetic acid in absolute ethanol $(30 \mathrm{ml})$. The mixture was refluxed for $7 \mathrm{~h}$, and the reaction was monitored by TLC, the yellow colored precipitate was formed and collected by filtration, dried and recrystallized from ethanol.

Synthesis of 7-hydroxy-4-(4-nitrophenyl)imino) methyl)-2H-chromene-2-one(2)

Yellow powder,yield 65\%;m.p. 201-204우; $\mathrm{IR}(\mathrm{KBr}) \quad v, \mathrm{~cm}^{-1}: 3481(\mathrm{OH})$ str., $1710(\mathrm{C}=\mathrm{O})$ str. of lactone, $1682(\mathrm{C}=\mathrm{C})$ str., 1624(C=N) str., 1592 and 1500 ( $\mathrm{Ar}-\mathrm{C}=\mathrm{C})$ str., $1389\left(\mathrm{NO}_{2}\right)$ str., 1068 (C-O) str. of lactone; ${ }^{13} \mathrm{CNMR}(100 \mathrm{MHz}), \mathrm{CDCl}_{3}, \delta$ ppm):162.61( $\mathrm{C}=\mathrm{O}$ lactone $), 160.46(\mathrm{C}=\mathrm{N}), 155.02$, 154.02, 154.00, 152.78 ,138.92, 128.52, 126.41, $125.99,113.26,111.07$, and 102.96(C-aromatic and alkene); mass spectroscopy Calcd. for $\mathrm{C}_{16} \mathrm{H}_{10} \mathrm{~N}_{2} \mathrm{O}_{5}$, (m/z,\%): $310\left[\mathrm{M}^{+} \cdot(31.2 \%), 293[\mathrm{M}-\mathrm{OH}](23.7 \%)\right.$, $264\left[\mathrm{M}-\mathrm{NO}_{2}\right](6.2 \%), 188\left[\mathrm{M}-\mathrm{C}_{6} \mathrm{H}_{4}-{ }_{p} \mathrm{NO}_{2}\right](3.7 \%)$, $161(7.5 \%)$.

Synthesis of 4-(4-acetylphenyl)imino)methyl)-7hydroxy-2H-chromene-2-one (3)

Yellow powder, yield 53\%;m.p. 187-189 ㄷ; IR) $(\mathrm{KBr}) \mathrm{v}, \mathrm{cm}^{-1}: 3359(\mathrm{OH})$ str., $3080 \mathrm{Ar}(\mathrm{CH})$ str.,2920 $\left(\mathrm{CH}_{3}\right)$ str., $1704(\mathrm{C}=\mathrm{O})$ str., $1670(\mathrm{C}=\mathrm{C})$ str., $1610(\mathrm{C}=\mathrm{N})$ str., 1589Ar $(\mathrm{C}=\mathrm{C})$ str., $1388\left(\mathrm{CH}_{3}\right)$ bend., and 1068(C-O) str. of lactone; ${ }^{13} \mathrm{CNMR}(100 \mathrm{MHz}), \mathrm{CDCl}_{3}$,

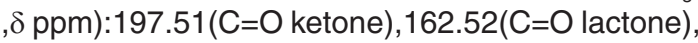
160.90(C=N),155.09,153.86,151.66,131.5 131.05,1 29.93,125.90,113.52,112.53,103.31(C-aromatic and alkene) and $26.07\left(\mathrm{CH}_{3}-\mathrm{C}=0\right)$;mass spectroscopy Calcd. for $\mathrm{C}_{18} \mathrm{H}_{13} \mathrm{NO}_{4},(\mathrm{~m} / \mathrm{z}, \%): 307[\mathrm{M}]^{+} \cdot(8.9 \%)$, 292(3.8\%), 264(12.8\%),188(5.1\%),161(3.8\%).
Synthesis of 4-(7-hydroxy-2-oxo-2H-chromene4-yl)methylene)amino)-1,5-dimethyl-2-phenyl$1 H$-pyrazole-3(2H)-one(4)

Intense yellow powder ,yield 71\%;m.p.192$195 \stackrel{\circ}{\circ}$; IR $(\mathrm{KBr}) v, \mathrm{~cm}^{-1}: 3300(\mathrm{OH})$ str.,3065 $\operatorname{Ar}(\mathrm{CH})$ str.,1718(C=O) str.of lactone 1652(C=C) str.,1137(C-N) str. of diazole, $1607(\mathrm{C}=\mathrm{N})$ str., $1507 \operatorname{Ar}(\mathrm{C}=\mathrm{C})$ str., $1403(\mathrm{OH})$ bend.,1368 $\left(\mathrm{CH}_{3}\right)$ bend.,1070(C-O) str. of lactone; ${ }^{13} \mathrm{CNMR}(100$ $\left.\mathrm{MHz}, \mathrm{CDCl}_{3}, \delta \mathrm{ppm}\right): 166.28(\mathrm{C}=\mathrm{O}$ lactone), $161.80(\mathrm{C}=\mathrm{O}$ cyclic amide), $160.90(\mathrm{C}=\mathrm{N}), 158.10,151$. 10,129.50,125.73,113.28,111.12, 103.25(C-aromatic and alkene),34.70 $\left(\underline{\mathrm{CH}}_{3}-\mathrm{N}\right), 18.73\left(\mathrm{CH}_{3}\right)$; mass spectroscopy Calcd. for ${ }_{21} \mathrm{H}_{17} \mathrm{~N}_{3} \mathrm{O}_{4},(\mathrm{~m} / \mathrm{z}, \%): 375$ $\left.[\mathrm{M}]^{+}\right)(7 \%), 374(3.3 \%), 188(6.6 \%), 161(13.3 \%)$.

Synthesis of ethyl 4-(7-hydroxy-2-oxo-2 Hchromene-4-yl)methylene)amino)benzoate (5)

Pale yellow powder, yield 44\%; m.p. 211 213으; IR(KBr)v, $\mathrm{cm}^{-1}: 3350(\mathrm{OH})$ str., $3080 \operatorname{Ar}(\mathrm{CH})$ str.,2978 $\left(\mathrm{CH}_{3}\right)$ str., $1760(\mathrm{C}=\mathrm{O})$ str. of lactone, $1745(\mathrm{C}=\mathrm{O})$ str., of ester,1682 $(\mathrm{C}=\mathrm{C})$ str., $1640(\mathrm{C}=\mathrm{N})$ str., 1597 and $1517 \operatorname{Ar}(\mathrm{C}=\mathrm{C})$ str., $1474\left(\mathrm{CH}_{2}\right)$ bend., 1389 $\left(\mathrm{CH}_{3}\right)$ bend., 1069(C-O) str. of lactone, 1044(C-O) str. of ester; ; ${ }^{13} \mathrm{CNMR}(100 \mathrm{MHz}), \mathrm{CDCl}_{3}$, $\delta$ ppm): 166.97 ( $\mathrm{C}=\mathrm{O}$ ester), 162.58( $\mathrm{C}=\mathrm{O}$ lactone), $160.74(\mathrm{C}=\mathrm{N}), 158.63,155.03,150.76,131.60$, $130.77,125.90,112.48,111.29,103.26(\mathrm{C}$-aromatic and alkene $), 60.56\left(\mathrm{CH}_{2}-\mathrm{O}\right), 14.42\left(\mathrm{CH}_{3}\right)$; mass spectroscopy Calcd. forC ${ }_{19} \mathrm{H}_{15} \mathrm{NO}_{5},(\mathrm{~m} / \mathrm{z}, \%): 337[\mathrm{M}]^{+}$ (32.4\%), 320[M-OH(9.5\%)],308[M- $\left.\mathrm{CH}_{3}-\mathrm{CH}_{2}\right](16.2 \%)$, $292\left[\mathrm{M}-\mathrm{CH}_{3} \mathrm{CH}_{2} \mathrm{O}\right](20.2 \%), 264\left[\mathrm{M}-\mathrm{CH}_{3} \mathrm{CH}_{2} \mathrm{CO}_{2}\right]$ (33.7\%).

Synthesis of 7-hydroxy-4-(5-mercapto-1,3,4thiadiazole-2-yl)imino)methyl)-2H-chromene-2one (6)

Pale yellow powder, yield 61\%;m.p.251$254 \stackrel{\circ}{\circ}$; IR(KBr)v, $\mathrm{cm}^{-1} 3380(\mathrm{OH})$ str.,3074Ar $(\mathrm{CH})$ str.,2550(SH) weak str.,1760 ( $\mathrm{C}=\mathrm{O}$ lactone) str., 1676 $(\mathrm{C}=\mathrm{C})$ str.,1639 $(\mathrm{C}=\mathrm{N})$ str.,1598 and $1505 \operatorname{Ar}(\mathrm{C}=\mathrm{C}) \mathrm{str} ., 1066(\mathrm{C}-\mathrm{O})$ str. of lactone; $\left.{ }^{13} \mathrm{CNMR}(100 \mathrm{MHz}), \mathrm{CDCl}_{3}, \delta \mathrm{ppm}\right): 181.11(\mathrm{C}-$ $\mathrm{SH}), 162.17(\mathrm{C}=\mathrm{O}$ lactone $), 158.88(\mathrm{C}=\mathrm{N}), 155.09$, 153.46, 113.24, 111.48 and 103.40 (C-aromatic and alkene);mass spectroscopy Calcd. for $\mathrm{C}_{12} \mathrm{H}_{7} \mathrm{~N}_{3} \mathrm{O}_{3} \mathrm{~S}_{3}$, $(\mathrm{m} / \mathrm{z}, \%): 305[\mathrm{M}]^{+} \cdot(4 \%), 304(4 \%), 272[\mathrm{M}-\mathrm{SH}]$ $(6.5 \%), 188(9.2 \%), 161(30.2 \%)$. 
Synthesis of amino acid Schiff bases (7-8) ${ }^{17-20}$

A solution of compound $1(0.01 \mathrm{~mol}, 1.9 \mathrm{~g})$ in absolute ethanol $(20 \mathrm{ml})$ was added dropwise to a homogenous solution of each amino acid $(0.01 \mathrm{~mol})$; glycine $(0.75 \mathrm{~g}$ and alanine $0.89 \mathrm{~g})$ and sodium hydroxide $(0.01 \mathrm{~mole}, 0.4 \mathrm{~g})$ in absolute ethanol $(20 \mathrm{ml})$ with continuous stirring. The solution's color changed immediately and after 2-3 minutes. $(1 \mathrm{ml})$ acetic acid was added. Stirring continued for $24 \mathrm{~h}$ and $12 \mathrm{~h}$ for glycine and alanine respectively, the obtained precipitate was collected by filtration, washed with cold ethanol, dried and recrystallized from methanol.

Synthesis of 2-(7-hydroxy-2-oxo-2H-chromene4-yl)methylene)amino)acetic acid (7)

Pale yellow powder, yield 61\%,m.p.198-200

${ }^{\circ} \mathrm{C}$; IR( $\left.\mathrm{KBr}\right) v, \mathrm{~cm}^{-1}: 3465$ phenolic $(\mathrm{OH})$ str., 3200$2500(\mathrm{OH})$ br.str., of carboxylic acid,3031 $\mathrm{Ar}(\mathrm{CH})$ str., 2987,2871 $\left(\mathrm{CH}_{2}\right)$ str., $1704(\mathrm{C}=\mathrm{O})$ str., reduced due to conjugation, $1640(\mathrm{C}=\mathrm{C})$ str., $1600(\mathrm{C}=\mathrm{N})$ str., $1500 \operatorname{Ar}(\mathrm{C}=\mathrm{C}) \operatorname{str} ., 1470\left(\mathrm{CH}_{2}\right)$ bend.

1410(OH) bend., $1071(\mathrm{C}-\mathrm{O})$ str.; $\left.{ }^{13} \mathrm{CNMR}(100 \mathrm{MHz}), \mathrm{DMSO}-d_{6}, \delta \mathrm{ppm}\right): 174.16$ ( $\mathrm{C}=\mathrm{O}$ carboxylic acid), 163.25( $\mathrm{C}=\mathrm{O}$ lactone), 161.01 $(\mathrm{C}=\mathrm{N}), 1$ 56.91, 154.16, 126.85,113.89, 111.69 and 106.05(C-aromatic and alkene), $56.52\left(\mathrm{CH}_{2}^{-}\right)$; mass spectroscopy Calcd. for
$\mathrm{C}_{12} \mathrm{H}_{9} \mathrm{NO}_{5},(\mathrm{~m} / \mathrm{z}, \%): 247[\mathrm{M}]^{+} \cdot(13.7 \%), 246(7.5 \%)$, 202(12.5\%), 188(15\%),161(82.5\%).

\section{Synthesis of 2-(7-hydroxy-2-oxo-2H-chromene-4-} yl)methylene)amino)propanoic acid(8)

Milky powder, yield 173-176 우 $\mathrm{IR}(\mathrm{KBr})$ v, $\mathrm{cm}^{-1}: 3364$ phenolic $(\mathrm{OH}), 3253-2503(\mathrm{OH})$ br.str of carboxylic acid, 3078Ar( $\mathrm{CH})$ str.,2948 $\left(\mathrm{CH}_{3}\right)$ str., 1720 $(\mathrm{C}=\mathrm{O})$ reduced due to conjugation, $1645(\mathrm{C}=\mathrm{C})$ str., $1617(\mathrm{C}=\mathrm{N})$ str., 1585 and $1519 \operatorname{Ar}(\mathrm{C}=\mathrm{C})$ str., 1411(OH) bend., 1361 $\left(\mathrm{CH}_{3}\right)$ bend.,1065(C-O) str.; $\left.{ }^{13} \mathrm{CNMR}(100 \mathrm{MHz}), \mathrm{DMSO}-d_{6}, \delta \mathrm{ppm}\right): 174.20(\mathrm{C}=\mathrm{O}$ carboxylic acid),165.1( $\mathrm{C}=\mathrm{O})$ lactone,161.18 $(\mathrm{C}=\mathrm{N}), 155.83,154.17,126.64,114.56,110.65,102.82$ (C-aromatic and alkene),56.8(CH-),18.60 $\left(\mathrm{CH}_{3}\right)$; mass spectroscopy Calcd. for $\mathrm{C}_{13} \mathrm{H}_{11} \mathrm{NO}_{5},(\mathrm{~m} / \mathrm{z}, \%)$ : $261[\mathrm{M}]^{+} \cdot(6 \%), 260(4.8 \%), 246\left[\mathrm{M}-\mathrm{CH}_{3}\right](5.4 \%)$, $229(42.1 \%), 216[\mathrm{M}-\mathrm{COOH}](12 \%), 188(10.8 \%)$.

\section{Antibacterial Activity}

The new title compounds 2-8 were screened for their preliminary antibacterial activity by using macro broth dilution method against two Grampositive $\left(\mathrm{G}^{+\mathrm{ve}}\right)$ bacteria Staphylococcus aureus and Micrococcus luteus, and two Gram-negative $\mathrm{G}^{\text {-ve) }}$ bacteria Escherichia coli and Pseudomonas aeruginosa to determine the MIC in vitro. A series of 13 tubes containing $1 \mathrm{ml}$ of Muller-Hinton media autoclaved and cooled then inoculated with 50

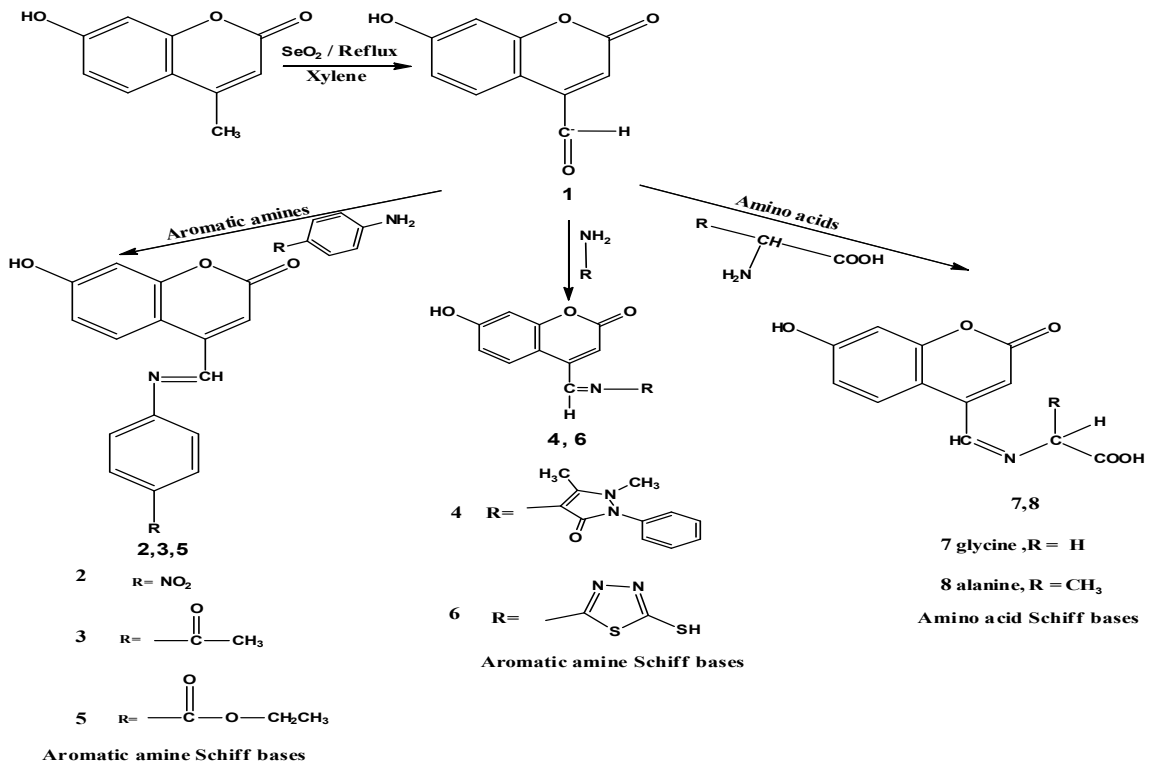

Scheme 1: Synthesis of title coumarin derivatives (2-8) 
$\mu$ bacterial inoculum of bacterial suspension at McFarland turbidity of 0.5 . Then defined concentrations of coumarin derivatives are added to each tube except the negative control in which the solvent (DMSO) was added and a positive control with bacterial inoculum without adding any coumarin derivative, all are incubated aerobically at $37^{\circ} \mathrm{C}$ for 24 hour, then MIC is determined by visual observation as the lowest concentration that inhibits bacterial growth appears clear solution.

\section{RESULTS AND DISCUSSION}

\section{Chemistry}

The new title coumarin derivatives, (Scheme 1) have been synthesized from 7-hydroxy4-methyl coumarin by oxidation of the methyl group $\left(\mathrm{CH}_{3}\right)$ at the carbon 4 , using $\mathrm{SeO}_{2}$ as an oxidizing agent and hot xylene, to afford 7-hydroxy-4-formy coumarin 1 , which is characterized by an IR band of aldehyde $(C=O)$ stretching displayed at $1698 \mathrm{~cm}^{-1}$, aldehydic hydrogen stretching $(\underline{\mathrm{H}-\mathrm{C}}=\mathrm{O})$ at 2850

Table1: Minimum inhibitory concentration(MIC) of coumarin derivatives 2-8 by using tube dilution method

\begin{tabular}{lcccc}
\hline $\begin{array}{l}\text { Compound } \\
\text { No. }\end{array}$ & $\begin{array}{c}\text { Staphylococcus } \\
\text { aureus }\left(\mathrm{G}^{+\mathrm{ve}}\right) \\
\text { Conc. } \mu \mathrm{g} / \mathrm{ml}\end{array}$ & $\begin{array}{c}\text { Micrococcus } \\
\text { luteus }\left(\mathrm{G}^{+\mathrm{ve}}\right) \\
\text { Conc. } \mu \mathrm{g} / \mathrm{ml}\end{array}$ & $\begin{array}{c}\text { Escherichia coli } \\
\left(\mathrm{G}^{-\mathrm{ve}}\right) \text { Conc. } \mu \mathrm{g} / \mathrm{ml}\end{array}$ & $\begin{array}{c}\text { Pseudomonas } \\
\text { aeruginosa }\left(\mathrm{G}^{-\mathrm{ve}}\right) \\
\text { Conc. } \mu \mathrm{g} / \mathrm{ml}\end{array}$ \\
\hline 2 & 79 & 40 & 123 & 192 \\
3 & 63 & 50 & 98 & 154 \\
4 & 40 & 63 & 192 & 240 \\
5 & 98 & 123 & 154 & 192 \\
6 & 40 & 40 & 98 & 79 \\
7 & 40 & 40 & 31 & 50 \\
8 & 300 & 240 & 192 & 123 \\
\hline
\end{tabular}

Note:C- = negative control (solvent,DMSO), $\mathrm{C}+=$ positive control indicates broth without adding any title coumarin derivative.

Table 2:Calculated chemical parameters of synthesized coumarin derivatives, using DFT with $3-21 \mathrm{G}^{*}$ basis.

\begin{tabular}{|c|c|c|c|c|c|c|c|}
\hline Comp & $\begin{array}{c}\text { highest } \\
\text { atomic } \\
\text { charge }\end{array}$ & $\begin{array}{c}\text { next } \\
\text { charge } \\
\text { value }\end{array}$ & $\begin{array}{l}\text { bond } \\
\text { angle } \\
\left({ }^{\circ}\right)\end{array}$ & $\begin{array}{l}\text { twist } \\
\text { angle } \\
\left({ }^{\circ}\right)\end{array}$ & $\begin{array}{l}\text { stretch- } \\
\text { bend }\end{array}$ & $\begin{array}{l}\text { torsion } \\
\left.\text { ( }{ }^{\circ}\right)\end{array}$ & stereochemistry \\
\hline 1 & $O(12)-0.440$ & $O(14)-0.239$ & 1.1036 & 4.7345 & 0.0187 & -5.9089 & $C(10)-C(9):(E)$ \\
\hline 3 & $\mathrm{O}(22)-0.719139$ & $\begin{array}{l}O(12)-0.616306 \\
N(14)-0.31403\end{array}$ & 1.8247 & 10.9945 & 0.1582 & -0.7736 & $\begin{array}{l}C(8)-C(9):(E) \& \\
C(13)-N(14):(Z)\end{array}$ \\
\hline 4 & $O(22)-0.719$ & $\begin{array}{l}O(12)-0.616 \\
\mathrm{~N}(14)-0.314 \\
\mathrm{O}(7)-0.208\end{array}$ & 1.8247 & 10.9945 & 0.1582 & -0.7736 & $\begin{array}{c}C(5)-C(4):(E) ; \\
C(12)-N(14):(Z) \text { and } \\
C(16)-C(22):(E)\end{array}$ \\
\hline 6 & $\mathrm{O}(3)-0.889268$ & $\begin{array}{l}N(18)-0.457364 ; \\
N(17)-0.330912\end{array}$ & 2.1491 & 24.6082 & 0.0802 & -1.6192 & $\begin{array}{l}C \text { (5)-C (4): (E) and } \\
\text { C (12)-N (14): (Z) }\end{array}$ \\
\hline 8 & O (18)-0.669779 & $\begin{array}{l}O(3)-0.638914 ; \\
\mathrm{N}(14)-0.237179 ; \\
\mathrm{O}(13)-0.195336\end{array}$ & 1.4799 & 6.6175 & 0.1416 & -13.2039 & $\begin{array}{c}C(15):(S) ; C(5)- \\
C(4):(E) \text { and } C(12)- \\
N(14):(E)\end{array}$ \\
\hline
\end{tabular}


$\mathrm{cm}^{-1}$, in addition, the ${ }^{13} \mathrm{CNMR}$-exhibited characteristic peak due to aldehydic $(\mathrm{C}=\mathrm{O})$ at $194.54 \mathrm{ppm}$.

The aromatic amine Schiff bases 2-6 produced in a satisfactory yield, and by the condensation of compound 1 with different aromatic amines using absolute ethanol as a solvent. The $(\mathrm{C}=\mathrm{N})$ band showed in the IR spectra at the range $1640-1607 \mathrm{~cm}^{-1}$ and in the ${ }^{13} \mathrm{CNMR}$-displayed characteristic peak at 160.90-159.88 ppm.

The amino acid Schiff bases 7-8 were prepared by the reaction of the compound 1 with each of glycine and alanine in a basic medium $(\mathrm{NaOH})$, using absolute ethanol as a solvent. The

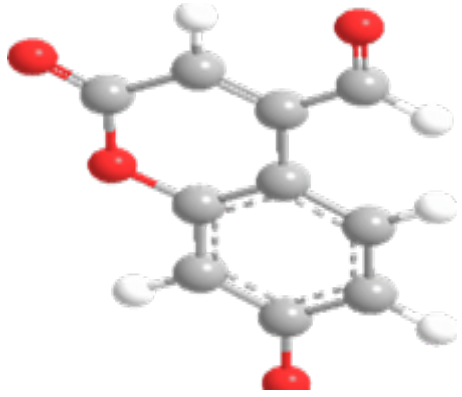

Compound 1

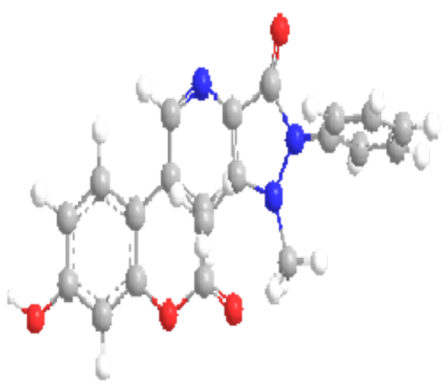

Compound 4

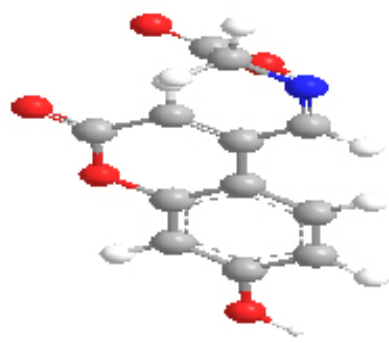

Compound 7
$(\mathrm{C}=\mathrm{N})$ stretching of the amino acid Schiff base, has been characterized in the IR at 1617 and $1600 \mathrm{~cm}^{-1}$ and in ${ }^{13} \mathrm{CNMR}$-displayed peaks at161.18 and $161.01 \mathrm{ppm}$ for alanine and glycine, respectively.

It must be noted, for the mass spectral data of each title compound 2-8, showed a characteristic peak $(\mathrm{m} / \mathrm{z})$ assigned the molecular ion peak $[\mathrm{M}]^{+}$, also, prominent peaks assigned for the fragment of each derivative,(experimental part).

\section{Antibactrial Activity}

From the results illustrated in table 2, showed that all title coumarin derivatives have

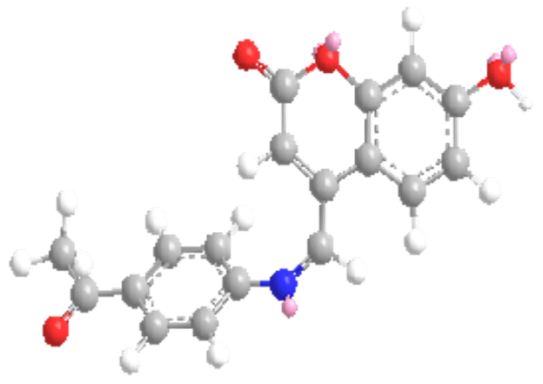

Compound 3

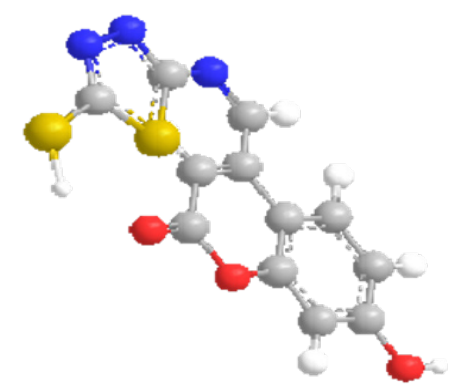

Compound 6

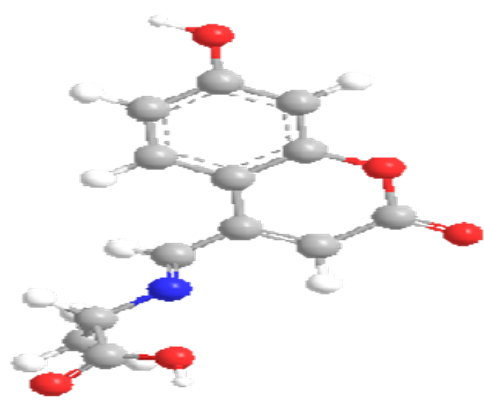

Compound 8

Fig. 1: Optimized 3D geometrical structures for compounds: 1,3, 4, 6,7 and 8 . 
antibacterial activity in vitro against both Gram positive and Gram negative bacteria with MICs range between $31-300 \mu \mathrm{g} / \mathrm{ml}$ in which they vary according to the derivatives and bacteria.

The lowest MIC is $31 \mu \mathrm{g} / \mathrm{ml}$ for compound 7, ( most potent), against Escherichia coli, and also
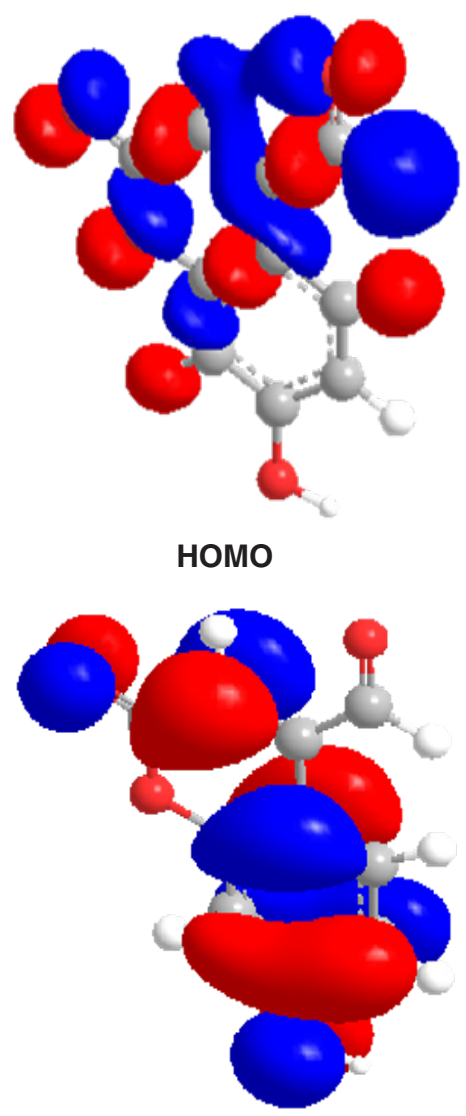

HOMO-1
MIC is $40 \mu \mathrm{g} / \mathrm{ml}$ observed for the compounds 6 and 7 against Gram-positive Staphylococcus aureus and Micrococcus luteus, respectively. While the highest MIC is $300 \mu \mathrm{g} / \mathrm{ml}$ for compound 8 against Staphylococcus aureus.

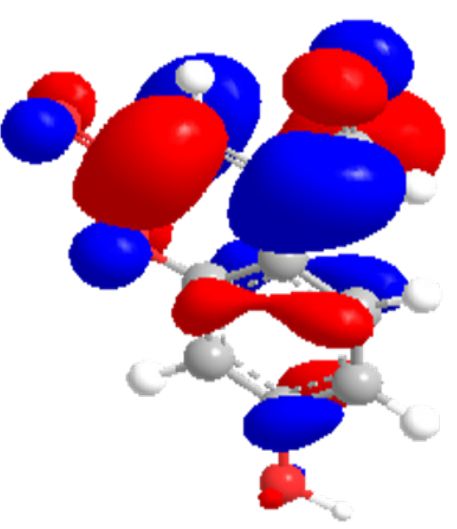

LUMO

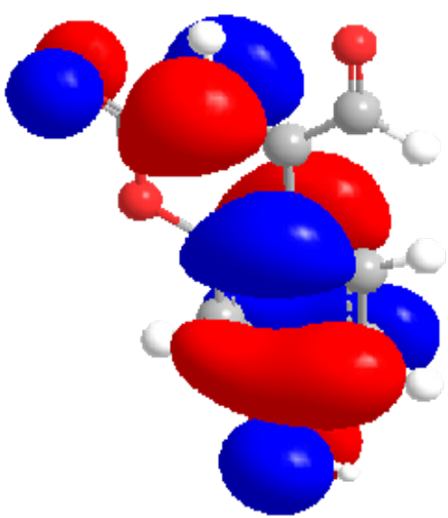

LUMO+1

Fig. 2: Highest occupied molecular orbital (HOMO) and lowest unoccupied molecular orbital (LUMO) of compound 1

Table 3: Global chemical reactivity of compounds 1, 3, 4, 6, 7 and 8

\begin{tabular}{lcccccc}
\hline Parameter & Comp.1 & Comp.3 & Comp.4 & Comp.6 & Comp.7 & Comp.8 \\
\hline Total energy (Kcal / mol) & 19.3707 & 43.2876 & 60.986 & 60.986 & 32.8275 & 19.4169 \\
Dipole moment (debye) & 7.0936 & 6.2501 & 7.7916 & 7.7916 & 13.5102 & 10.0628 \\
Log P & 0.42 & 1.85 & 0.99 & 3.18 & 0.14 & 0.63 \\
electronic chemical potential $(\mu)$ & $-8,893$ & -7.574 & -0.053 & -1.3075 & -7.087 & -4.375 \\
chemical hardness $(\boldsymbol{\eta})$ & 1.966 & 0.914 & 0.051 & 1.0085 & 1.624 & 1.585 \\
electrophilicity $(\omega)$ & 20.174 & 31.38 & 0.0274 & 0.847 & 15.464 & 6.013 \\
\hline
\end{tabular}


Table4: HOMO and LUMO energies (eV) of title coumarin derivatives

\begin{tabular}{llllllll}
\hline Comp. HOMO & LUMO & $\begin{array}{c}\Delta E \\
(\mathbf{e V})\end{array}$ & HOMO-1 LUMO+1 & $\begin{array}{c}\Delta E \\
(\mathbf{e V})\end{array}$ \\
\hline 1 & -10.859 & -6.927 & -3.932 & -12.294 & 0.029 & -12.323 \\
3 & -8.488 & -6.66 & -1.828 & -11.5 & -3.293 & -8.207 \\
4 & -0.104 & -0.002 & -0.102 & -0.55 & 1.912 & -2.462 \\
6 & -2.316 & -0.299 & -2.017 & -4.128 & 0.303 & -4.431 \\
7 & -8.711 & -5.463 & -3.248 & -12.045 & -0.315 & -11.73 \\
8 & -5.945 & -2.769 & -3.176 & -9.477 & -0.293 & -9.184 \\
\hline
\end{tabular}

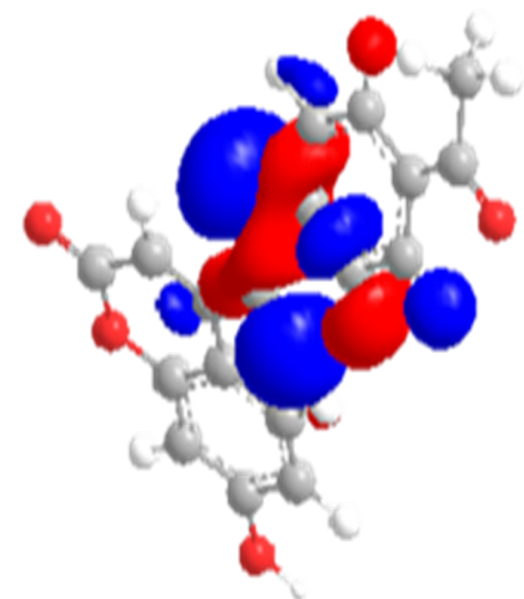

HOMO

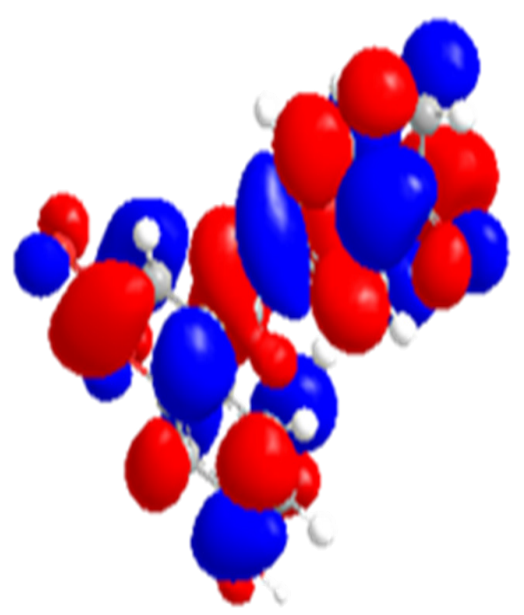

HOMO-1

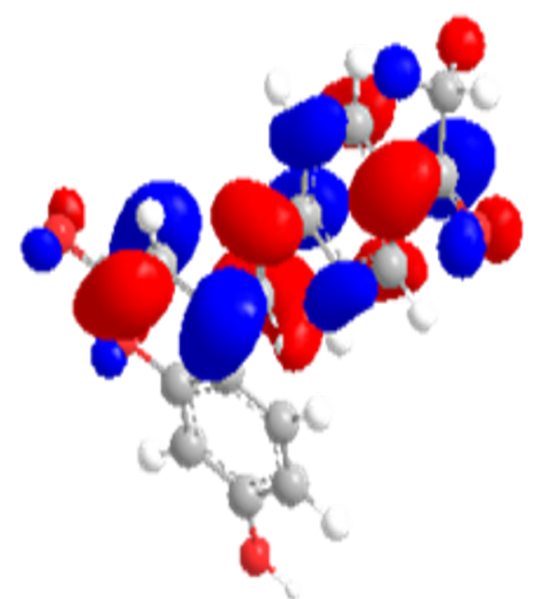

LUMO

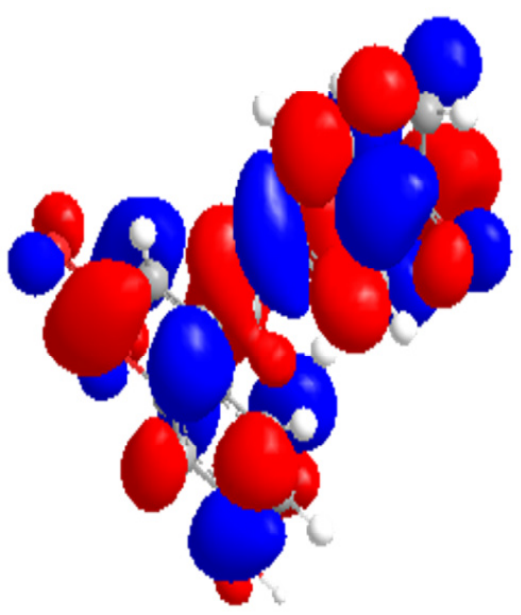

LUMO+

Fig. 3: Highest occupied molecular orbital (HOMO) and lowest unoccupied molecular orbital (LUMO) of compound 3 


\section{Computational Studies}

The quantum chemical calculations were validated on the new coumarin derivatives using Density Functional Theory (DFT) methodology with $3-21 \mathrm{G}^{*}$ basis,while the molecular atomic charges were approved using the Mulliken population analysis.

The molecular representation sketch of the new coumarin compounds was plotted using Chem. Bio-Office 2010 software.

The following chemical parameters calculated using DFT are: total energy (E), chemical hardness $(\eta)$, electronic chemical potential $(\mu)$ and electrophilicity $(\omega)$

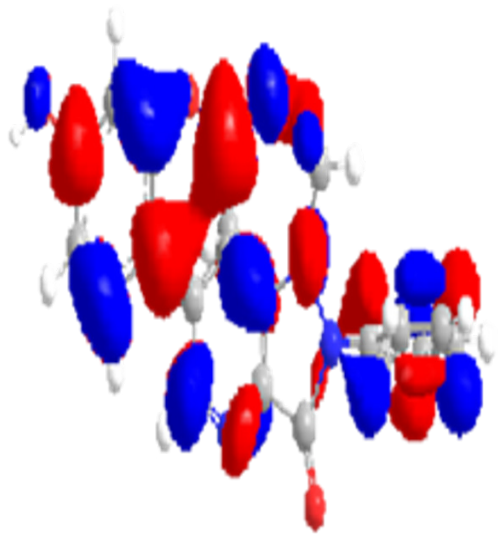

HOMO

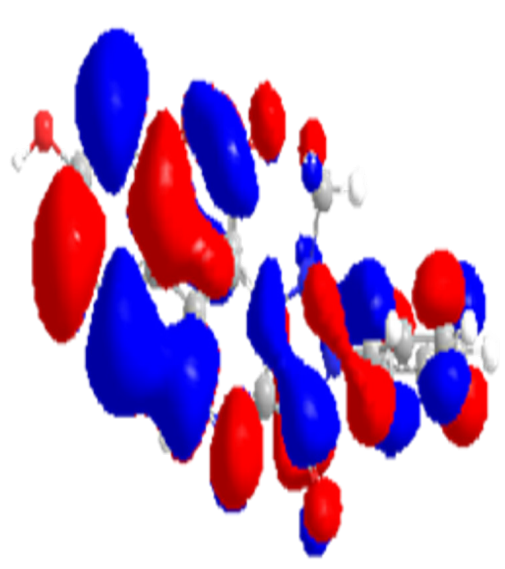

HOMO-1

\section{Structural and electronic properties}

Compounds $1,3,4,6,7$ and 8 with optimized geometries and 3D geometrical structures are demonstrated in figure 1, and the data listed in table 2 showed the highest atomic charge of all coumarin compounds 1-8 and confirmed the atoms are the most reactive toward the addition substitution reactions. The calculated bond angle and twist angle, stretch. , bend, stretch-bend, torsion and stereochemistry, indicated the title coumarin derivatives are non-planar molecules.

The quantum mechanical method have been approved for compounds 1, 3, 4, 6,7 and 8 . The molecular structure (optimized form) of the most stable one is shown in figure 1 . While the

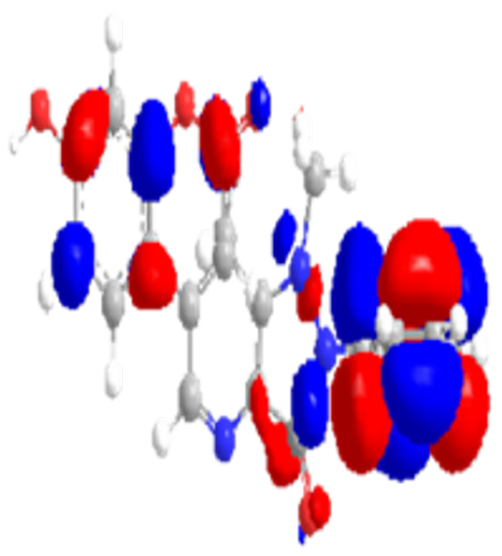

LUMO

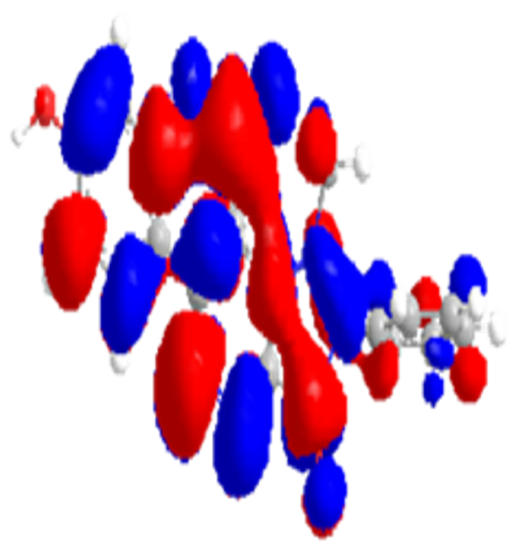

LUMO+1

Fig. 4: Highest occupied molecular orbital (HOMO) and lowest unoccupied molecular orbital (LUMO) of compound 4 
calculated energies are presented in table 3 . The contour plots of the frontier orbitals for the ground state of compounds $1,3,4,6,7$ and 8 are shown in the figures: 2, $34,5,6$ and 7 together with the Highest Occupied Molecular Orbital (HOMO) and the Lowest Unoccupied Molecular Orbital (LUMO).

Table5: Electron density for title coumarin derivatives

\begin{tabular}{|c|c|c|c|c|}
\hline Comp. & HOMO & LUMO & $\begin{array}{l}\text { Electron density } \\
\text { HOMO-1 }\end{array}$ & LUMO+1 \\
\hline 1 & $\begin{array}{l}\text { carbonyl group } \\
\text { substituted on } \\
\text { coumarin }\end{array}$ & $\begin{array}{l}\text { coumarin and } \\
\text { carbonyl } \\
\text { group } \\
\text { substituted on } \\
\text { coumarin }\end{array}$ & coumarin ring & $\begin{array}{l}\text { phenol ring of } \\
\text { coumarin, and also } \\
\text { carbonyl group that } \\
\text { substituted on } \\
\text { coumarin }\end{array}$ \\
\hline 3 & $\begin{array}{l}\mathrm{C}=\mathrm{N} \text { - bond } \\
\text { between } \\
\text { benzene ring } \\
\text { and coumarin } \\
\text { ring }\end{array}$ & $\begin{array}{l}\text { on } \mathrm{C}=\mathrm{N}- \\
\text { bond between } \\
\text { benzene ring } \\
\text { and coumarin } \\
\text { ring, and } \\
\text { carbonyl of } \\
\text { ketone and } \\
\text { coumarin ring }\end{array}$ & $\begin{array}{l}\mathrm{C}=\mathrm{N}-\text { bond between } \\
\text { benzene ring and } \\
\text { coumarin ring, and } \\
\text { carbonyl of ketone and } \\
\text { coumarin ring }\end{array}$ & $\begin{array}{l}\text { on } \mathrm{C}=\mathrm{N} \text { - bond between } \\
\text { benzene ring and } \\
\text { coumarin ring, and } \\
\text { carbonyl of ketone }\end{array}$ \\
\hline 4 & $\begin{array}{l}\mathrm{N}-\mathrm{N} \text {-bond } \\
\text { of the five- } \\
\text { member, on } \\
\text { coumarin ring } \\
\text { and methyl }\end{array}$ & whole molecule & whole molecule & $\begin{array}{l}\mathrm{N}-\mathrm{N}-\text { bond of five- } \\
\text { member, on } \\
\text { coumarin ring, and the } \\
\text { phenol group of } \\
\text { coumarin ring }\end{array}$ \\
\hline & $\begin{array}{l}\text { groups of } \\
\text { diazo ring }\end{array}$ & & & \\
\hline 6 & $\begin{array}{l}\mathrm{N}-\mathrm{N} \text {-bond } \\
\text { of five- } \\
\text { member and on } \\
\text { coumarin } \\
\text { ring }\end{array}$ & $\begin{array}{l}\text { lactone ring of } \\
\text { coumarin, } \\
\mathrm{N}-\mathrm{N} \text {-bond of } \\
\text { five- } \\
\text { member, and } \\
\mathrm{C}=\mathrm{N} \text { group } \\
\text { between } \\
\text { coumarin and } \\
\text { thiadiazole }\end{array}$ & $\begin{array}{l}\mathrm{N}-\mathrm{N} \text {-bond of } \\
\text { five-member and on } \\
\text { coumarin ring }\end{array}$ & $\begin{array}{l}\text { phenol ring of } \\
\text { coumarin }\end{array}$ \\
\hline 7 & $\begin{array}{l}\mathrm{C}=\mathrm{N} \text { group } \\
\text { between } \\
\text { coumarin and } \\
\text { carboxylic acid }\end{array}$ & $\begin{array}{l}\mathrm{C}=\mathrm{N} \text { group } \\
\text { between } \\
\text { coumarin and } \\
\text { carboxylic acid }\end{array}$ & whole molecule & $\begin{array}{l}\mathrm{C}=\mathrm{N} \text { group between } \\
\text { coumarin and carboxylic } \\
\text { acid and phenol ring of } \\
\text { coumarin }\end{array}$ \\
\hline 8 & $\begin{array}{l}\mathrm{C}=\mathrm{N} \text { group } \\
\text { between } \\
\text { coumarin and }\end{array}$ & $\begin{array}{l}\text { on } \mathrm{C}=\mathrm{N} \text { group } \\
\text { between } \\
\text { coumarin and } \\
\text { carboxylic acid }\end{array}$ & $\begin{array}{l}\mathrm{C}=\mathrm{N} \text { group } \\
\text { between coumarin and } \\
\text { carboxylic acid }\end{array}$ & $\begin{array}{l}\text { on } \mathrm{C}=\mathrm{N} \text { group between } \\
\text { coumarin and carboxylic } \\
\text { acid and phenol ring of }\end{array}$ \\
\hline & carboxylic acid & $\begin{array}{l}\text { and } \\
\text { coumarin }\end{array}$ & & coumarin \\
\hline
\end{tabular}


It is remarkable to view that both orbitals are considerably circulated over the conjugation plane. In addition, it can also be seen from the figures 2-7 that the HOMO orbitals are located on the substituted molecule, while LUMO orbitals look like those obtained for the unsubstituted molecule and therefore, the substitution has contributed a control on the electron donation ability while influencing only a small effect on electron acceptance ability. Table 4. Showed the HOMO and LUMO gap. The lower values in the HOMO and LUMO energy gap would give details the eventual electron- donor-acceptorcomplex interaction occurring within the molecules. The values of HOMO for compounds 1, 3, 4, 6,7 and 8 are low. Indicate these molecules have low ionization energies inferring that, they can lose the electrons easily ${ }^{20}$. Chemical hardness is related with the stability and reactivity of a chemical compounds, it measures the resistance to change in the electron distribution or charge transfer. The molecule with the higher HOMO-LUMO energy gap, is harder and more stable/less reactive molecule..

Electronic chemical potential $(\mu)$ is known as the negative of electronegativity of a molecule ${ }^{21}$ and describes the escaping tendency of electrons from an equilibrium system. Global electrophilicity index $(\omega)$, is calculated using the electronic chemical potential and chemical hardness. This index measures capacity of a species, to accept

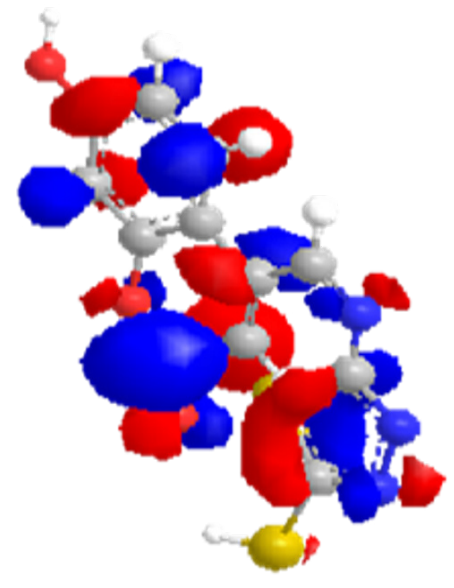

HOMO

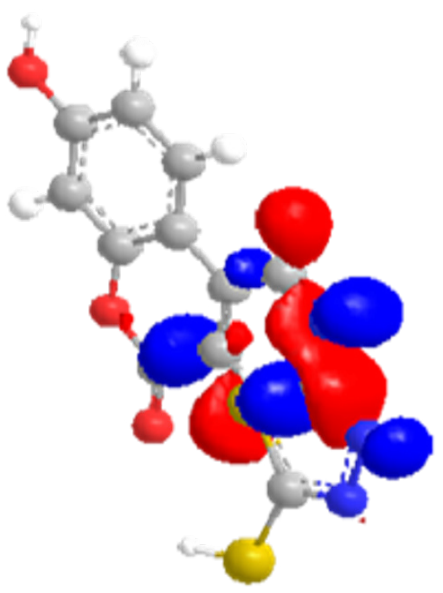

HOMO-1

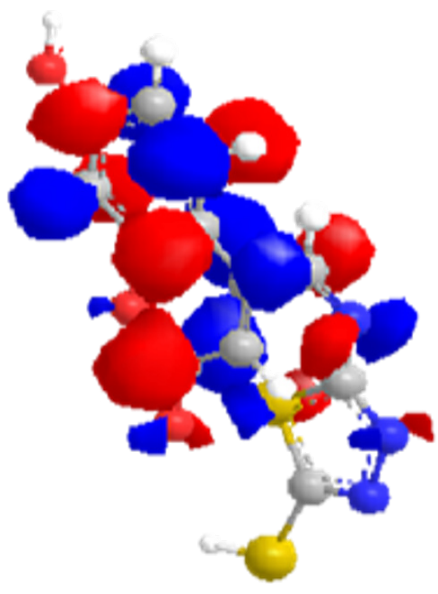

LUMO

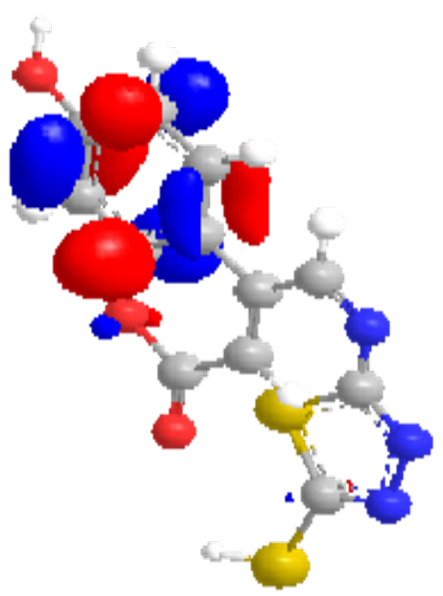

$\mathrm{LUMO}+1$

Fig. 5: Highest occupied molecular orbital (HOMO) and lowest unoccupied molecular orbital (LUMO) of compound 6 
electrons ${ }^{22,23}$. It is a total of the stabilization in energy after a system accepts an additional amount of electronic charge from the environment ${ }^{24}$.

Table 3 (row 5)contains the computed chemical hardness values for compound 1,3,4,6,7 and 8 . The consequences indicate that compound 1 is harder and less reactive than compound 3 which is harder and less reactive than compound 4 . The values of $(\mu)$ for compound $1,3,4,6,7$ and 8 are shown in Table 3 (row 4). The trend in electronic chemical potential for compound $4>$ compound $6>$ compound $8>$ compound $7>$ compound $3>$ compound 1 .

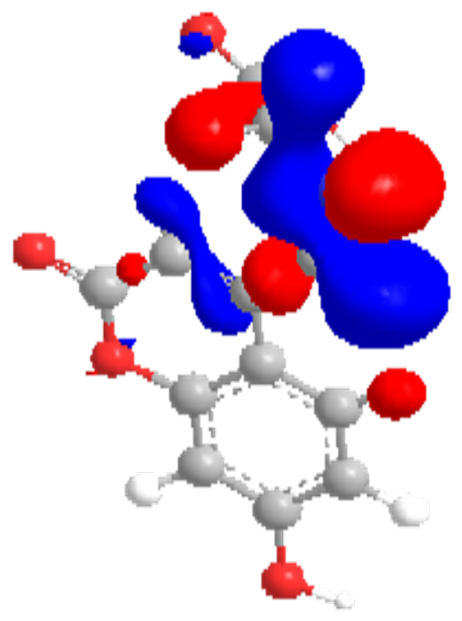

HOMO

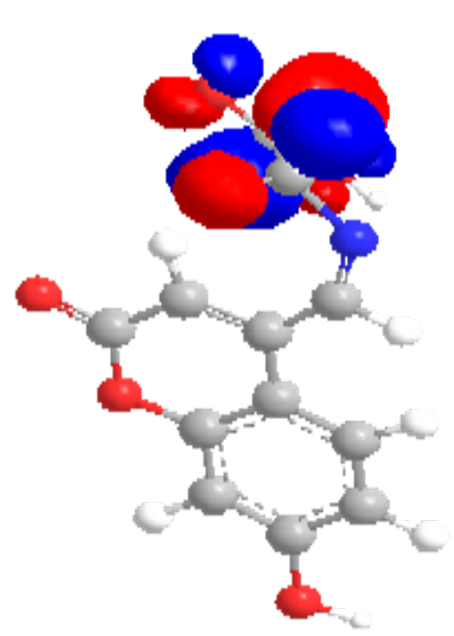

HOMO -1
The dipole moments, total energy $(E)$, the partition coefficient $(\log P)$, chemical hardness $(\eta)$, electronic chemical potential $(\mu)$ and electrophilicity $(\omega)$ of compounds 1, 3, 4, 6,7 and 8. were also calculated and listed in Table 3.

The more reactive or less stable compound, is the higher chemical potential,. Therefore, compound 4 is the more reactive than other compounds. While compound 1 is the least reactive. The electrophilicity values $(\omega)$ (Table3, row 6 ) for the compound 1,3,4,6,7 and 8 are $20.174 \mathrm{eV}, 31.38 \mathrm{eV}, 0.0274 \mathrm{eV}, 0.847$ $\mathrm{eV}, 15.464 \mathrm{eV}$ and $6.013 \mathrm{eV}$, respectively. Among the compounds, compound 3 is considered the strongest

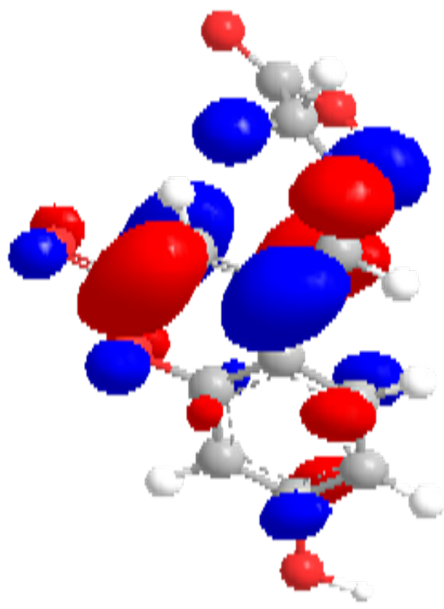

LUMO

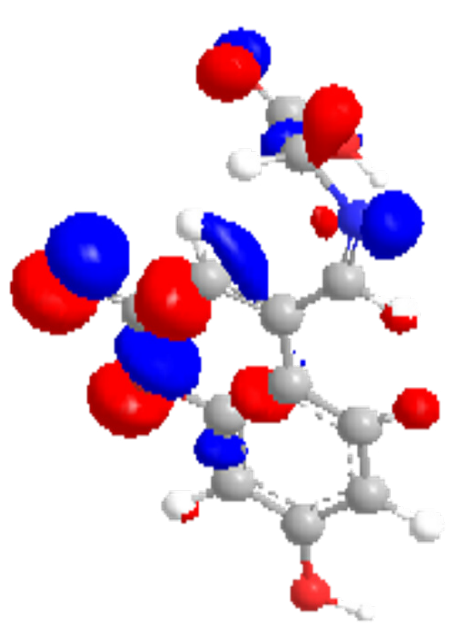

HOMO +1

Fig. 6: Highest occupied molecular orbital (HOMO) and lowest unoccupied molecular orbital (LUMO) of compound 7 
nucleophile while compound 1 is considered as a strongest electrophile.

\section{Electrostatic potential charges and related quantum chemical properties}

The distribution of the electronic density (electrostatic potential charges), related quantum chemical parameters [dipole moment (Table 3, row 2), and the partition coefficients of the compounds ( $\log$ P; Table 3, row 3) were calculated for observed compound 1,3,4,6,7 and 8 . These values and properties are very helpful and can be used in order to estimate chemical properties and possibilities for the interaction of compounds 1,3,4,6,7 and 8 with target sites (receptors, enzymes) as well as their transporting system through the cell membranes and brain-blood barrier. All these structural, electronic parameters and log $\mathrm{P}$ can be used for a construction

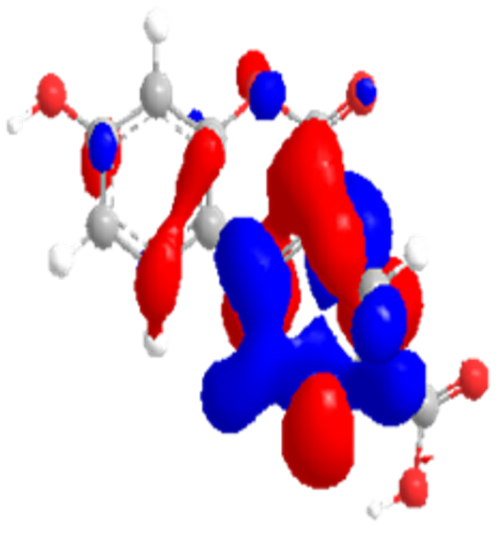

HOMO-1
HOMO

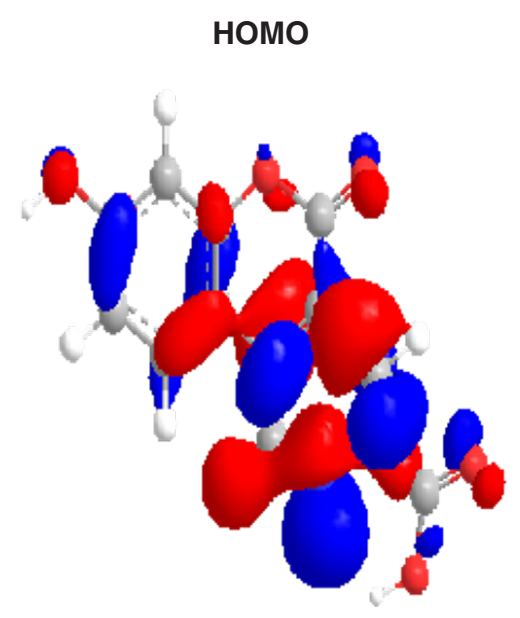

of quantitative structure-activity relationship (QSAR) model because all of them are closely correlated to pharmacokinetics and pharmacodynamics properties ${ }^{21}$.

Redox potential can be measured from HOMO/LUMO gap; it is significant for the oxidativemetabolism pathway involving cytochrome P450 enzymes. The observed HOMO/LUMO gap , $(\Delta \mathrm{E})$ (Table 4), is used to calculate redox potential. The lower negative values of both HOMO and LUMO energies designate that these compounds have the general properties of the reductors. This information may be significant for drug metabolism, as the oxidation (and sometimes the reduction) is the main metabolic pathway for many drug molecules.

All title coumarin derivatives are polar

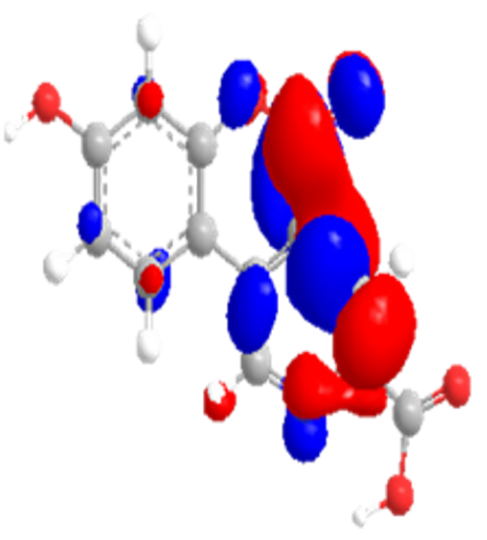

LUMO

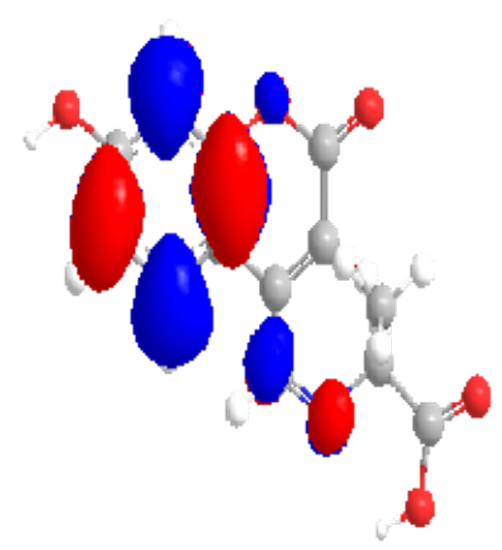

LUM0+1

Fig. 7: Highest occupied molecular orbital (HOMO) and lowest unoccupied molecular orbital (LUMO) of compound 8 
molecules, depending on their electric dipole moments (Table 3), The most polar molecule is compound 7 , while compound 6 is found to be the most lipophilic according to the log $\mathrm{P}$ values (Table 3row 3).

The UV-VIS absorption spectra of the compounds: 1 , 3and 4 were recorded in (ethanol). The absorption peaks are observed at 248,287 and $222 \mathrm{~nm}$, and 267 and $295 \mathrm{~nm}$ for the compounds 6 , 8. It can be conclude that these peaks imply to the $n \rightarrow p^{*}$ and $p \rightarrow p^{*}$ transitions. The 3D plots of the, HOMO-1, HOMO, LUMO, LUMO+1, and the corresponding energy levels of the compounds 1, 3, 4,6,7 and 8 are shown in the figures 2, 3,4,5 and 6, respectively. The theoretical electronic transfer (ET) for compound 1, 3,4,6 were corresponding to the UV-VIS spectral absorption peaks and the electronic transfer of HOMO plus LUMO and HOMO plus LUMO+1, respectively. The increased theoretical absorption wavelengths of the title compounds have slight blue-shifts.

Figures 2-7 showed the six main orbitals that have contributed in the vertical electronic transitions for compounds 1, 3, 4, 6, and 8. These orbitals, namely, HOMO-1, HOMO, LUMO, and LUMO+1, represent the three highest occupied orbitals and three lowest unoccupied orbitals in the compounds 1, 3, 4, 6,7 and 8. Similar spatial distribution of orbitals between $\mathrm{HOMO} / \mathrm{HOMO}-1$ and LUMO/LUMO+1 pairs and the population analysis for compounds $1,3,4,6,7$ and 8 , are listed in table 5.

\section{CONCLUSION}

In the present work a series of new coumarin derivatives have been synthesized from 7-hydroxy4-methylcoumarin by the oxidation of methyl group at $\mathrm{C} 4$ of the parent coumarin nucleus, using $\mathrm{SeO}_{2}$, to produce formyl group, then the formation of different derivatives under conventional method. The title coumarin derivatives were screened for their preliminary antibacterial activity using serial dilution method, by determining their minimum inhibitory concentrations (MIC), and showed moderate to highest antibacterial activity against Gram-positive and Gram-negative bacteria.

Compound 7 showed the highest antibacterial activity against Gram- positive Staphylococcus aureus and Micrococcus luteus, and potent antibacterial activity against Gramnegative E.coli. The synthesized derivatives were studied theoretically by using DFT calculations., and the stereochemistry was estimated and found that compounds $1,3,4,6,7$ and 8 . are not- planar molecules.

\section{ACKNOWLEDGEMENT}

We are grateful to Dr.Emad M. Alkhafaji / Faculty of Science-School of Chemistry, University of Sulaimani, for continuous help and discussions during the work, also many thanks to School of Pharmacy /Dept. of Pharmaceutical ChemistryUniversity of Sulaimani, for providing laboratory facilities and carrying out the research.

\section{REFERENCES}

1. Musa, M.A.; Badisa, V.L.; Latinwo, L.M.; Cooperwood, J.; Sinclair, A.; Abdullah, A. Cytotoxic activity of new acetoxycoumarin derivatives in cancer cell lines. Anticancer. Res., 2011, 31, 2017-2022.

2. Borah, P.; Naidu, P.S.; Bhuyan, P.J. Synthesis of some tetrazole fused pyrido[2,3-c]coumarin derivatives from a one-pot three-component reaction via intramolecular 1,3-dipolar cycloaddition reaction of azide to nitriles. Tetrahedron. Lett., 2012, 53, 5034-5037.
3. Barot, K.P.; Jain, S.V.; Kremer, L.; Singh, S.; Ghate, M.D. Recent advances and therapeutic journey of coumarins: Current status and perspectives. Med .Chem .Res., 2015, 24, 2771-2798.

4. Céspedes, C.L.; Avila, J.G.; Martínez, A.; Serrato, B.; Calderón-Mugica, J.C.; SalgadoGarciglia, R. Antifungal and antibacterial activities of Mexican tarragon (Tagetes lucida). J.Agric.Food .Chem., 2006, 54, 3521-3527. 
5. Saleem, M.; Nazir, M.; Ali, M.S.; Hussain, H.; Lee, Y.S.; Riaz, N.; Jabbar, A. Antimicrobial natural products: An update on future antibiotic drug candidates. Nat. Prod .Rep.,2010, 27, 238-254.

6. Yu, Y.M. The antibacterial effects and mechanism of several botanical compounds against Ralstonia solanacearum. Master's Thesis, Southwest University, Chongqing, China, 2015.

7. Abu-Hussen, A.A.A. Synthesis and spectroscopic studies on ternary bis-Schiffbase complexes having oxygen and/or nitrogen donors. J.Coord .Chem., 2006,59,157-176.

8. Sithambaram, K,M.; Jagadesh, P,D.; Poojary, B.; Subramanya, B. Synthesis and biological activity of Schiff and Mannich bases bearing 2,4-dichloro-5-fluorophenyl moiety, K. Bioorg. Med. Chem., 2006, 14, 7482-7489.

9. Singh, K.; Barwa, M. S.; Tyagi, P. Synthesis, characterization and biological studies of $\mathrm{Co}(\mathrm{II}), \mathrm{Ni}(\mathrm{II}), \mathrm{Cu}(\mathrm{II})$ and $\mathrm{Zn}(\mathrm{II})$ complexes with bidentate Schiff bases derived by heterocyclic ketone. Eur.J.Med.Chem., 2006, 41(1),147153

10. Pannerselvam, P.; Nair, R. R.;Vijayalakshmi, G.; Subramanian, E. H.; Sridhar, S. K. Synthesis of Schiff bases of 4-(4-aminophenyl)-morpholine as potential antimicrobial agents.Eur.J.Med Chem., 2005,40,225-229.

11. Taymaa, A. L. A.; Farouk, K.; Sameh ,H.; Nizam ,A. A. Synthesis and characterization of new Schiff bases containing coumarin derivatives and study their antimicrobial and antioxidant activities, AASCIT J.Chem., 2015, 2(1), 1-6.

12. Mashelkar Uc, Jhams, Mashelkar Bu. Synthesis of 2-azetidinones substituted coumarin derivatives. J. Serb. Chem Soc. 2012;77(10),1339-1344.

13. Kini SG.; Choudhary,S.; Mubeen, M. Synthesis, docking study and anticancer activity of coumarin substituted derivatives of benzothiazole J.Comput.Methods.Mol Des., 2012,2(1),51-60.

14. Mashelkar,UC.;Audi, A.A. Synthesis of some novel 4-substituted coumarins having potential biological activity (Part III). Indian.
Chem., 2006,45B(06),1463-1469.

15. Creaven ,BS.; Devereux, M.; Karcz, D.;Kellet, A.; McCann, M., Copper(II) complexes of coumarin-derived Schiff bases and their anti-candida activity. J.Inorg. Biochem., 2009, 103(9),1196-1203.

16. Dömötöra, O.; Tuccinardi, T.; Karcz, D.; Walshd, M.; Creaven, BS.; Enyedy, ÉA. Interaction of anticancer reduced Schiff base coumarin derivatives with human serum albumin investigated by fluorescence quenching and molecular modeling. Bioorg. Chem., 2014,28(52),16-23.

17. Hamid, J.SH; Kubba, M. A.R. Ammar. Synthesis, and characterization of new coumarin derivatives containing various moieties. Int.J.Pharma. Pharm. Sci., 2015,7(8), 70-74.

18. Azzouz,A.S.P.; Ali, RT. Synthesis of Schiff bases derived from benzaldehyde and salicylaldehyde with some amino acids by a new develop method. NJC.,2010,7,158-68.

19. Kumar ,DN.;Sharma, P.; pareek, A. Synthesis of new Schiff-base complexes and their applications. Int.J.App. Res., 2013, 2,307.

20. Rîmbu, C.; Danac, R; Pui, A. Antibacterial activity of $\mathrm{Pd}(\mathrm{II})$ complexes with salicylaldehyde-amino acids Schiff bases ligands. Chem.Pharm.Bull., 2014,62(1),1215.

21. Kadhum, A. A. H., Al-Amiery, A. A., Shikara, M., Mohamad, A. Synthesis, structure elucidation and DFT studies of new thiadiazoles. Int. J. Phys. Sci., 2011, 6(29), 6692-6697.

22. Vektariene A., Vektaris G. and Svoboda j. A theoretical approach to the nucleophilic behavior of benzofused thieno[3,2-b]furans using DFT and HF based reactivity descriptors Arkivock, 2009,7,311-329

23. Parr R G., Szenpaly L ,Shibun Liu., Electrophilicity index J.Am.Chem. Soc., 1999,121(9),1922-1924

24. Stanchev, S., Mitkov, J., Georgieva, M., Zlatkov, A. DFT study of the physicochemical characteristics and spectral behavior of new 8-substituted 1,3,7-trimethylxanthines. Int.J. Quantum. Chem. 2013, 113, 1384-1393. 